\title{
The Foreign Element in the British Army, 1793-1815
}

\section{Captain C. T. Atkinson}

To cite this article: Captain C. T. Atkinson (1914) The Foreign Element in the British Army, 1793-1815, Royal United Services Institution. Journal, 58:433, 289-320, DOI: 10.1080/03071841409423042

To link to this article: http://dx.doi.org/10.1080/03071841409423042

册 Published online: 11 Sep 2009.

Submit your article to this journal $₫$

山 Article views: 12

Q View related articles 5 


\section{THE JOURNAL \\ OF THE}

\section{ROYAL UNITED SERVICE INSTITUTION.}

VOL. LVIII. MARCH, I9I4. No. 433.

[Authors alone are responsible for the contents of their respective .Papers.]

\section{THE FOREIGN ELEMENT IN THE BRITISH \\ ARMY, 1793-1315.}

By Captain C. T. Atkinson, Oxford University O.T.C.

On Wednesday, October 2gth, rgr3.

Professor C. W. OMan in the Chair.

THE CHAiRMaN : I will now ask Captain Atkinson to read his paper on the Foreign Element in the British Army during the Republican and Napoleonic Wars, a subject on which (as I am sure you will agree when you have heard the paper) he possesses an absolutely unrivalled knowledge. He has even succeeded in exhuming from the ashes of the past several regiments, of which, I believe, that no living person has heard even the names.

\section{LECTURE.}

NOT even the most casual reader of Napier's Peninsular IVar can have failed to notice that-even apart from the Spaniards and the Portuguese-the forces whom Wellington led to so many victories were not exclusively British. $H$ is best light cavalry regiment was the Ist Hussars of the King's German Legion, so closely associated with Craufurd's famous Light Division in the outpost work of the Army; the most brilliant example of shock action given by the mounted arm during the whole war was the charge of the Dragoons of the Legion at Garcia Hernandez on the day after Salamanca; unaided by artillery or infantry, they shattered three squares of intact French infantry. A brigade of Line battalions of the Legion served in nearly every action between the Douro and Bayonne, suffering 
enormous losses at Talavera; the two Light Battalions were conspicuous by their steady conduct at more than one critical moment in the retreat from Burgos. And though one would search the Army Lists of to-day in vain for the Brunswick Oels and the Chasseurs Britanniques, who figure so constantly in Napier's pages, those regiments were part of the British Army. In all, four cavalry regiments out of the twenty-five, ten infantry battalions out of the eighty-five who at one time or another served under the Iron Duke, were composed wholly or in the main of men of non-British origin, and in other quarters of the globe, notably in the Mediterranean garrisons, and in the West Indies, the proportion of foreigners was even higher. Yet, even so, the British forces were not nearly so cosmopolitan as the "French" Armies of the day. Among the troops led against them by Napoleon's marshals in the Peninsula were Poles, Italians, Dutchmen and Swiss, as well as regiments from every quarter of Germany, and of the half-million of men who invaded Russia in 1812 only about one-third were native Frenchmen.

\section{FOREIGN SOLDIERS IN THE XVIIIT CENTURY.}

The employment of foreign soldiers, unnatural and surprising as it seems to those accustomed to the nationalized armies of the present day, was a commonplace of the $I$ th and I 8th century military economy, which not even the Revolution had entirely swept away. Thus, under the Ancien Régime, the French Army had not only included Swiss, who earned imperishable renown by their defence of the Tuileries, and the scarcely less famous Irish Brigade, but it contained half a dozen German regiments and two of Italians, and the most successful commander of French Armies between the days of Louis XIV. and the Revolution was a foreigner, Marshal Saxe, whose best lieutenant was Loewendahl, a Dane. In the Prussian service one meets Scottish Jacobites like Marshal Keith; in the Austrian Army the names of Lacy, Loudoun and Browne bear witness to the British origin of some of the most distinguished defenders of the Hapsburg monarchy. In Spain there were, besides the ubiquitous Swiss and the celebrated Walloon Guards, the Irish regiments of Ultonia, Hibernia, and Irlanda, which were still partly recruited from Ireland at the time of the Peninsular War, while many of the leading Spanish commanders, notably Blake and Henry O'Donnell, were of Irish descent. Religious intolerance and loyalty to a fallen dynasty were responsible for the presence in foreign armies of so many men of British origin, but the mercenary pure and simple who would give his services to any power who would pay and feed him well was ubiquitous. Every nationality was represented in the Russian Army, and the Dutch service contained Swiss and German regiments, as well as a Scots Brigade, which only came to an end in $178 \mathrm{I}$, when Holland's recognition 
of the revolted American colonies involved her in war with Great Britain. That brigade, revived in 1793 in the British service, became the old $94^{t h}$, who served with such conspicuous valour in India and the Peninsula, and though disbanded in 1818 were re-raised in 1823 , and are now the 2 nd Connaught Rangers.

\section{GREAT BRITAIN'S PRACTICE.}

Great Britain was indeed distinguished from the other nations of Europe, inasmuch as the employment of foreign soldiers in the British Isles was actually illegal in peace. 'In war time the absence of any system by which the exiguous and underpaid forces of Great Britain could be adequately and promptly expanded drove us repeatedly to panic-stricken efforts to hire troops from those minor German principalities which, like Brunswick and Hesse-Cassel, maintained disproportionately large armies, who served as one of their chief sources of income; but a nation so morbidly afraid of military despotism as to be frightened even by its own shadow of an Army, was proportionately more nervous of foreign soldiers, and the most elaborate precautions were taken to provide safeguards against the use of Hessians or Hanoverians to the detriment of the constitution. It never seems to have occurred to our politicians that if our national establishments were framed on an adequate scale, there would be no need to call in Hessians, as in 1745 , to help against the Jacobites; or, as in 1756 , to allay the nation's fears in that famous invasion scare; or to send Anhalters and Waldeckers across the Atlantic to subdue our revolted colonies.

But while the foreign troops so frequently employed in the I 8 th century were only auxiliaries, called in for a constantly recurring "temporary emergency," and did not form part of the British Army, there was one regiment on the permanent establishment of King George III.'s service which was mainly recruited from foreigners. This was the famous 6oth, raised as the Royal Americans in 1756, under an Act (29 Geo. Il. Sect. 5) which legalized the enlistment of foreign soldiers and the granting of commissions to foreign officers, but limited their services to America. The regiment was partly raised among the Swiss and German settlers who had recently arrived in Pennsylvania and the Carolinas, and among its most distinquished officers were two Swiss, Bouquet and Haldimand, of whose merits Captain Lewis Butler's recently published History of the King's Royal Rifle Corps provides ample evidence. In I 793 the 60 th had four battalions, the rank and file being mainly British, though as its services were still confined by statute to America and the West Indies, the practice seems to have grown up of drafting into it recaptured deserters and men sentenced by court-martial, who commuted their sentences by serving in an unhealthy climate. Of the officers less than a third seem to have been foreigners, to judge by the Army Lists of the period. 
It does not come within the scope of this paper to explain why on the outbreak of the Great War only some 20 squadrons of cavalry and half a dozen weak battalions of infantry could be scraped together to form Great Britain's contribution to the land forces of the First Coalition, still less is it my purpose to discuss how much expense and suffering might have been avoided had our military establishments been less hopelessly inadequate. But in this emergency it was natural that Pitt and Dundas should have recourse once again to the practice of hiring foreigners to do the work which the citizens of Great Britain were unwilling or unprepared to do. In their schemes for obtaining these substitutes they displayed a wonderful and sanguine ingenuity : hardly a European country but was at one time or another the promised land from which the much-needed troops were to be forthcoming. Repeated disappointments might well have taught Pitt the lesson, "if you want a thing done, do it yourself." It was indeed "a most wasteful and extravagant economy," which rendered us unable to fight our battles for ourselves. As has been well said, " no policy could have been less calculated to bring the war to an end than that of subsidizing German armies over which this country had no direct control."

\section{TYPES OF FOREIGNERS EMPLOYED.}

With such subsidized allies, such as the 62,000 Prussians whom Pitt thought he had secured for the defence of the Netherlands in 1794, but who never did anything to earn the money spent upon them, this paper is not concerned. Strictly speaking, these troops, though supported out of British funds, were not in British pay, still less part of the British Army. Great Britain did not as a rule deal direct with the troops she subsidized, but with the monarchs and their ministers. Hence this form of paying others to fight one's battles was much the most unsatisfactory, a constant source of trouble and discord. The troop-producing country did not regard the acceptance of a subsidy as in any way impairing its right to dispose of its own soldiers, and was by no means prepared to hand them over completely to the Power who defrayed their equipment and maintenance. We paid the piper, but the tune played was not as a rule that for which we had called.

In a second category come troops which, though never part of the British Army, were definitely in British pay and under the command of British generals. Among these one would reckon the Portuguese, the Spaniards, in and after the Vittoria campaign, and those Hessians and Hanoverians who formed so large a part of the force with which the Duke of York endeavoured to defend the Netherlands at the beginning of the war. These last were excellent troops, better far than the bulk of the hastily-raised, untrained and ill-officered levies who masqueraded as British regiments in 1794 . The Hanoverians in 
particular were worthy successors of the men who had fought at Minden or shared in gallant old Eliott's stout-hearted defence of Gibraltar. The force obtained for the campaign of 1793 amounted to nearly 34,000: 18,000 Hanoverians, 12,000 from Hesse-Cassel, 3,000 from Hesse-Darmstadt, 750 from Baden,

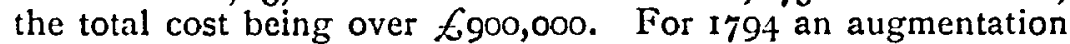
of seven battalions of infantry and additional pioneers and artillery, 5,300 in all, was obtained from Hanover, and over 2,000 Brunswickers were added, but Great Britain did not long enjoy the services of these auxiliaries. In I795 the Peace of Basle neutralized North Germany and put a stop to the employment of the Hanoverian Army and to the hiring of Hessians and Brunswickers. A treaty was made with Hesse-Darmstadt in 1796 for the services of three battalions which were to be employed anywhere except as marines or in the East Indies, but they actually served with the Austrians in South Germany and never came in touch with British troops. A good many men were recruited in Germany by British agents even after I795, but the transport of these recruits to England presented considerable difficulties, the North German Powers being zealous in upholding their neutrality even to the extent of denying the use of their ports for this purpose. Colonel Nesbitt, the officer in charge of the foreign corps, complains in a letter of August, 1796, of the obstructive attitude recently adopted by the Duke of Oldenburg.

\section{THE CONDÉAN ARMY.}

There is one force which belongs to this second category to which a peculiar interest attaches, the little army of emigrés raised by the Prince of Condé in 1792. This was partly recruited from the Swiss, German, and Irish regiments in the French service, several of which came over almost bodily, being unaffected by the rise of nationalist sentiment which caused their French comrades to transfer their allegiance from the monarchy to the national assembly when Louis XVI. clearly showed that he was looking to foreigners to assist him against his own subjects. Among these was one regiment of the old Irish Brigade, that of Bervick. The bulk of the Condéans, however, were ex-officers reduced to serving in the ranks. This little force suffered many strange vicissitudes. Taken into British pay in the autumn of I794 just in time to prevent the dissolution of the force from sheer want, the greater part of the Condéans continued to serve with the Austrians in South Germany till July, I797, only one regiment, the Salm Hussars, actually entering the British service. In July, 1797, the Condéans were transferred to the Czar's service, and had to betake themselves to Russia. In March, I800, Czar Paul quitted the Second Coalition, whereupon the relics of the Condéans were once again taken into British pay, and continued to serve in South Germany till in I8or the Peace of Lunéville put an end to 
the struggle on the Continent. On this, most of the Condéans accepted the inevitable and took their discharge, many returning to France and making their peace with the Consulate. But there was an insatiable remnant who were not yet prepared to abandon their opposition to the regicide government, and some 700 of these men were formed into a regiment of the British Army under the title of the Chasseurs Britanniques, the commissions of their officers dating from May, 1801, though the regiment does not appear in the Army List till I804. It saw service in its new capacity almost at once, being shipped off to Egypt and arriving in time to assist in the reduction of Alexandria, in which the remnant of Napoleon's invading army was holding out.

\section{FOREIGN REGIMENTS IN THE BRITISH ARMY.}

The majority of the foreigners employed by Great Britain during the war actually formed part of the British Army. Their officers received the King's commission and took rank accordingly, more than one of them commanded brigades and even divisions in the Peninsula and elsewhere. Many of the regiments appear in the Army Lists, but unfortunately this only became normal in the later stages of the war. Before the Peace of Amiens it is the exception, which greatly increases the difficulties of tracing elusive corps like Dillon's, the Loyal Emigrants, and Rohan's Hussars. De Roll's Swiss regiment, for example, makes its first appearance in the Army list in I 8o3, though its officers' commissions in the regiment dated from 1794. Sometimes the same man raised more than one corps. Thus in 1793 one finds a Hussar regiment raised by Baron Hompesch in Germany, but in a list of foreign corps in the British service in January, 1796, the only "Hompesch's" is a corps of Fusileers, not yet completed to its establishment, and the $5^{\text {th }}$ Battalion of the 6oth, raised in 1798 , is usually said to have been formed out of Hompesch's Chasseurs. Then from August, I798, till May, I8oo, Hompesch's Mounted Rifles appear in the Army Lists. After that the Monthly List knows them no more, but they continue to figure in the Annual Lists for another two years, while one hears of "Hompesch's Light Dragoons" as contributing a troop to Abercromby's army in Egypt. The explanation seems to be that Hompesch's Hussars so took the fancy of the Prince of Wales that he conferred on them the name of "Prince of WVales' Hussars" in I 795, under which title they went out to San Domingo to perish. The Chasseurs are accounted for by the addition of several companies of riflemen, some foot, some mounted, to the Fusileer regiment, and after that unit died out the mounted companies preserved a separate existence, being indifferently called "Mounted Rifles" and "Light Dragoons."

Again, the absence of a regiment from the Army List of any particular year is no proof that it was not then in vigorous 
existence. Thus Abercromby had with him in Egypt a Foreign Brigade of three battalions : Dillon's, de Roll's, and Stuart's, the last of these, though in date of formation it was several years the junior, is the only one which is mentioned in the Army List of the year. Similarly the issue of a letter of service to a particular individual authorizing him to raise a corps by no means proves that that particular unit cver came into existence. The IVar Office records teem with proposals for raising regiments, often from people who were quite unfitted to do so, and were merely seeking an opportunity of getting money advanced to them. Even the units which were actually formed are hard to trace. Ephemeral in origin and doomed to certain dissolution once peace should be restored these foreign regiments were nobody's children. Liable to be reduced and drafted at short notice they baffle and elude research into their individual fortunes. No one has troubled to write their history, or even to chronicle their formation and dissolution. Their records are a tissue of obscurities and uncertainties. After I800, however, one is much assisted by the publication as Appendices to the Commons' Journals of the estimates of the year as well as of a large number of returns ordered by the House. From these it is possible to obtain a good deal of definite information and to compile accurate statistics as to the number of foreigners raised, discharged and lost. But for the earlier years of the Great War nothing so satisfactory is forth. coming, and one is often forced to have recourse to mere conjecture. A good deal can be learnt from the War Office papers now in the Public Record Office, but the information they supply is somewhat fragmentary.

\section{SOURCES FROM WHICH RECRUITS CAME.}

Recruits for these foreign regiments were obtained from several different sources. First and foremost come the emigrés, who were keenly anxious for an opportunity of avenging their monarch's death and their own misfortunes, and could be relied upon to do good service. But though in 1793 and 1794 Western Germany, the Netherlands and the South of England teemed with these men, the supply was limited, and after I795 very few new recruits of this character were to be obtained. The first emigré corps to be formed was raised by Lord Mul. grave at Toulon, during the English occupation of that port. This regiment, the Royal Louis, accompanied the British when they were driven out, and after assisting to reduce Calvi ultimately found its way to Portsmouth, to be absorbed into one of the regiments raised for the ill-fated expedition of 1795 to Quibéron. For this nearly a dozen corps seem to have been specially formed, being raised in England and the Channel Islands, while some others which had already taken part in the Netherlands campaign of 1794, and been brought to England in the spring of 1795, were also employed. It was a 
disastrous venture, to the fatal issue of which the enlistment of prisoners of war contributed in no small degree. Some of the emigré regiments, notably d'Hectors, were completed in this fashion, and the prisoners naturally took the first opportunity of assisting the cause they really favoured. How many of the unlucky emigrés perished in this tragedy it is impossible to say, but the loss must have run into thousands, for in October, 1794, eight of the regiments employed had averaged $45^{\circ}$ a piece, and a return dated Quibéron Bay, July 26th, 1795, gives the survivors as barely 1,000. Apparently some of the emigré regiments were so fortunate as not to arrive in time to share in the disaster, for several units which had been raised for this expedition were still in existence in January, I796, and three emigré regiments, those of de Castries, de Mortemart, and la Chatre, also known as the Loyal Emigrants, survived till after the Peace of Amiens, going out to Portugal with Charles Stuart in 1797 . The Loyal Emigrants had served in the Netherlands in 1794, and had been almost cut to pieces near Nieuport.

The emigrés were regarded by the soldiers of the Republic with peculiar bitterness and received no quarter. On the surrender of Bois le Duc some 400 emigrés who formed part of the garrison were at once put to death in cold blood, and one reads in 1799 that the idea of employing in the expedition to North Holland de Mortemart's and the other emigré regiments. then in Portugal was abandoned, because it was unfair to employ these regiments on outpost, "a situation exposing them to the greatest danger," for capture meant certain death.

The raising of all regiments had been legalized by an Act of Parliament, which had received the Royal Assent in May, 1794. By this (34 Geo. III. Sect. 43) the enlistment of French subjects in regiments to serve on the Continent of Europe and in certain other places was authorized, and the King was empowered to grant commissions to French officers, subject to certain restrictions. The chief of these were that these foreign troops might be landed in England if it was necessary, as, for instance, when troops were being collected for some distant expedition. Not more than 5,000, raised ten years later to 10,000, might be on shore at once, and these troops were not to move more than five miles inland, so nervous was Parliament of the unconstitutional uses to which foreigners might be put. One finds the King sending a special message to Parliament in December, 1795, explaining that some of the foreign troops on passage from the Elbe and Weser to Spithead, " the place of rendezvous for the convoy under which it was intended they should be sent on distant foreign service," had had to be disembarked owing to stress of weather, but should be re-embarked as soon as possible.

These troops from the Elbe and Weser were the regiments which had taken part in the defence of the Netherlands and 
shared in the disastrous retreat to Bremen. Most of them were composed of emigrés, notably the Choiseul Hussars, who formed part of a foreign brigade to the command of which Sir John Moore was appointed in December, 1795. He speaks of this corps in the warmest terms, both officers and men were extremely good; however, the regiment refused to volunteer for West Indian service, and was in consequence broken up in the course of 1796. The York Fusileers, also known as Hardy's, a regiment which figures in the Army List, and had 5o per cent. of British officers, was also among the troops under Moore's command, together with the York Rangers, one of the earliest corps formed, of which practically all the officers were foreigners. Artillery were also included among the foreign corps, there being French, German and Dutch gunners, amounting in all to some 800 to 900 . The French artillery were particularly good: they had been raised at Toulon, and were composed of sailors, apparently those trained seamen-gunners whom the Republican passion for equality would not permit to enjoy the privilege of pointing the guns of their country at the ships of King George.

In the course of 1796 the bulk of the surviving emigres seem to have been sent to the West Indies, and there they may be said to be still. Swept away wholesale by yellow fever and the other scourges, which made service in those islands so deadly and so deservedly unpopular, many corps perished outright. A list of foreign corps in the British service in January, 1796, shows four cavalry regiments and thirteen infantry units already raised, besides some artillery, a so-called Legion for San Domingo, and three battalions in process of formation. Five years later only five of these were still in existence, and the end of corps like Rohan's Hussars, the Uhlans Britanniques, the York Rangers and York Fusileers, are shrouded in mystery. Sometimes one is able to identify the date at which the remnant of some unit was transferred to the insatiable 6oth. Thus one finds the $3 / 60$ th receiving into its ranks in February, 1798, the survivors of La Tour's or the Royal Foreigners, a corps of Dutchmen, which had come out to the West Indies with Abercromby in 1796, and served with some credit under Moore at St. Lucia. It is spoken of as a very fine corps, and seems to have been distinctly above the average.

There is one of these emigré corps which is of special interest, both because it survived to the end of the war, and because of its connection with the famous Irish Brigade in the French service. This was Dillon's, one battalion of which surrendered to the British in San Domingo in the autumn of 1793 , and took service with its old enemies. But one meets accounts of the raising in Europe of another battalion, apparently out of the officers and men of the regiment who had been serving in France. In January, I 795, several Irish officers were transferred to this corps, and twelve months later it certainly had 
two battalions and was nearly $1,5^{00}$ strong. One reads early in I 795 of arrangements for shipping it from Leghorn to Corsica, and in 1797 it was in Portugal, still two battalions strong, its sank and file being almost wholly French. Charles Stuart, under whom it was, gave an unflattering account of its discipline, but by I 800 it had improved enough to be included in Abercromby's force, for a battalion of Dillon's was in the Foreign Brigade which behaved so steadily in the battle of March 2 Ist, 1801, outside Alexandria. The regiment was one of the last to evacuate Egypt, and was then sent to Gibraltar, being about 400 strong. That happened to the battalion at San Domingo is uncertain; an officer of Dillon's was wounded at San Domingo in 1797 ; probably, like most regiments whom evil fortune took to that island, it perished there.

Something of an effort seems to have been made to get Irish recruits for Dillon's, but without much success; nor did better fortune attend the effort to raise an Irish Brigade of six battalions to be officered as far as possible by ex-officers of the old Irish regiments in the French service. Authorized in the autumn of 1794 , it was actually raised, but only completed by enlisting foreigners, and though sent to the West Indies, it proved of little service. Its records are very incomplete, and do not enable one to fix the date of its dissolution, but it is not included in the Army List for 1 799 , and was then apparently extinct.

\section{GERMAN AND SWISS REGIMENTS.}

But the emigrés were not the only recruits available. A certain number of Germans seem to have been obtained, mercenaries pure and simple, of the old-fashioned condottieri type. What is remarkable is to find that in 1799 the 6oth had two recruiting companies in Germany, as well as a regular recruiting agent at Pyrmont. I have already shown how difficult it was to export recruits from Germany after the Peace of Basle. One finds a recruiter complaining in 1797 that the obstacles to recruiting are now so great that he cannot raise men at the old price of $\mathcal{E}_{20}$ a head. But Hompesch's various corps and Lowenstein's two regiments, like Hompesch's the ancestors of the $5 / 6$ oth, were certainly Germans, and one finds Germans being drafted out of the emigré regiments in Portugal to help form the 6th Battalion of that same regiment in 1799 . Lowenstein's original corps, the Chasseurs, had been in the Dutch service, but transferred to the British on the French occupying Holland in 1795 . The Fusilecrs were raised in Germany in 1796 , while in I80o, after the other two regiments had died out, Lowenstein raised yet a third corps, Lowenstein's Jägers, who joined the British in Egypt in July, I801, coming from Trieste. La Tour's Dutch corps, the Royal Foreigners, already mentioned, can only be regarded as mercenaries, and there were many such men among the foreign regiments sent to the West 
Indies in 1795 and 1796 , for Abercromby complains bitterly of their misconduct, and of the indifferent character of the material of which they were composed.

The experiment of enlisting.prisoners of war was not always as unsatisfactory as it had proved in the Quibéron tragedy. When in 1795 Ceylon was captured from the Dutch, a useful regiment, nearly I,000 strong, was added to the British Army. This was de MLeuron's, a Swiss corps, which transferred itself wholesale from the Dutch service to that of Great Britain. This regiment was the property of a Swiss nobleman, M. de Meuron, and one comes across in the Parliamentary papers notices of payments to him. Thus, in November, 1798, he was awarded $E_{50,000}$ on account of services rendered by him in Ceylon, and he seems to have been paid a subsidy of $\$_{3}$,ono annually as long as the regiment remained in our service. For the first ten years of its existence it was in India, being maintained by the East India Company at an annual cost of $£ 33,000$. It did good service there, sharing in the storm of Seringapatam in 1799 , and we have Vellington's testimony to its merits, though he adds that the natives of India never regarded the regiment with the respect with which they looked on British corps, for knowing that its men were not British by nationality, they believed them to be purchased slaves.

Another regiment, with an even more distinguished record than de Meuron's, was added to the British Army in the same way. When in I798 Charles Stuart captured Minorca, there were among the prisoners over a thousand Swiss who had been taken by the French from the Austrians in Italy, and had literally been sold to the Spaniards at two dollars a head. Out of these men a battalion was formed, originally called Stuart's, after its colonel, or the Minorca Regiment. It says a great deal for its colonel and officers, that a regiment which had started its career in none too promising a fashion, should have turned out very well. In Abercromby's victory at Alexandria it did really well, standing up to the charges of the French cavalry in gallant style and repulsing them. It had over 200 casualties, and one of its men received a special reward for his gallant conduct and capture of a French colour. In recognition of its good conduct the regiment was honoured in I802 with the title of the "Queen's Germans."

The military reputation of the Swiss has always stood high, and it is not wonderful that Pitt and Dundas should have had their eyes fixed on a country which has been traditionally the home of gallant soldiers of fortune. But the Swiss authorities, anxious not to offend their powerful neighbour, seem to have been disinclined to allow recruiting, and though a letter of service was issued in December, I794, to a Swiss nobleman, Baron de Roll, authorizing him to raise a regiment, it had to be levied on the confines of Switzerland. The corps seems to have been fairly quickly raised, for early in 1795 it was ordered 
to embark at Leghorn for Corsica. On the evacuation of Corsica it proceeded to Portugal, where it came under Charles Stuart. That officer's first report of it was none too favourable, but he seems to have worked wonders with it, for in 1798 it is described as "a very fine regiment," well disciplined, and composed of men who had sacrificed everything to their adherence to the cause of their country. Losses on service and by shipwreck had depleted it so much that it had had to be cut down from two battalions to one. In 1801 it went to Egypt with Abercromby, although not bound by its capitulation to serve outside Europe, and was in the Foreign Brigade which did so well at Alexandria. When the bulk of the foreign corps were disbanded at the Peace of Amiens, de Roll's was among the regiments which were spared, as was also Stuart's, both regiments being provided for in the 1803 Estimates for the whole year.

But the chief effort to utilize Switzerland as a source of recruits was made in 1799 , when the forces of the Second Coalition re-occupied the greater part of the country and drove out the French troops, who had in the previous year attacked and subjugated the Swiss cantons. No less than $£_{14} 40,000$ was expended in attempting to raise Swiss troops, and Colonel Craufurd, later to achieve fame as the leader of Wellington's Light Division, was among the officers employed on this service. He does not appear to have been particularly suited to the task, for he quarrelled with Mr. Wickham, the chief British agent in those parts, and an Austrian officer describes him as more fitted in temperament for command in the field. Pitt had hoped to obtain at least 10,000 men, but it would seem doubtful if a fifth of that number were raised. However, they included one regiment which was well worth adding to the Army. This was de Watteville's, raised by an officer of that name who belonged to an old Bernese family, and had been in the Dutch service earlier in the war. His regiment was raised. out of the wrecks of the little Bernese Army, which had gallantly but vainly opposed the French invasion of Switzerland led by Brune in I798. The regiment, on being taken into British pay, served with the Austrians until the end of 1800 , after which they came under the direct control of the British Government, and were shipped off to Egypt to reinforce Abercromby. They arrived too late for the battle of Alexandria, but did good service in the siege of that town. I have had the good fortune of getting some information about the regiment from a member of the de Watteville family. He points out that the regiment had excellent reasons for their hostility to the French, who had not only overthrown the liberties of their country, but had reduced them individually to beggary: the de Watteville family plate, for example, went to Egypt with Bonaparte. Later on the property of all Swiss fighting against Napoleon was confiscated, and the anti-French feeling in Berne continued 
to be extraordinarily bitter even to 1870 . The regiment was almost exclusively officered by Bernese, and to the end the N.C.o.'s were mainly Swiss, though later on in the war it proved difficult to keep the ranks full of Swiss. Louis de WVatteville had seen something of most armies before he joined the British service, and his impressions of the British Army are interesting. Two things in particular struck him : the great severity of the discipline, and the amount of care taken over target practice. Thus, on one occasion, when the regiment was on board H.M.S. "Pomone," the troops were exercised daily at musketry, shooting at floating targets, while in addition, owing to the crew being short-handed, the soldiers were called upon to complete the gun's crews and practised every week. The Duke of Kent, who had known Baron de W'atteville personally for many years, took a particular interest in the regiment, and stood its friend when friction arose between its proprietor and the agent for the foreign troops. It is perhaps worth mentioning also, that the last survivor of the regiment died in 1884 , he had joined the corps in 1813 as a boy of 16 .

One other effort to obtain recruits was even less successful than the attempt to get Swiss. When the British landed in North Holland in 1799 there were high hopes of obtaining help from the partisans of the Orange family, and some 3,000 men, largely deserters and prisoners of war, were collected at the Helder, though as so often happens the expected assistance proved a broken reed. On the evacuation of the country these Dutchmen were transferred to the Isle of Wight, and in i8oo an Act was passed to allow the King to give commissions to the subjects of the Prince of Orange and to enlist such men. Four regiments of infantry and a battalion of chasseurs, with artillery and pioneers were to be formed to serve in Europe, and in the estimates for I 801 provision was made for the maintenance of nearly 8,000 Dutch troops at a cost of about $£ 250,000$. Some of these Dutch battalions were employed in Ireland, but they saw no active service and were paid off in June, 1802 .

The occupation of Corsica had been followed by the enlistment of natives of the island. A militia of some three battalions was formed soon after the capture of Calvi with Corsican officers, but it was not a great success, being ill-disciplined and giving a great deal of trouble. "A regiment of foot to serve in Corsica" figures in the Army Lists of I794 to 1797, and one meets references to it in accounts presented to Parliament, but it does not seem to have survived the evacuation of the island, and "Colonel Montresor's Anglo-Corsican corps " is not to be identified with the Corsican Rangers. This regiment was formed at Minorca out of Corsicans who had attached themselves to the British when the island was evacuated. Under the command of Hudson Loweit went to Egypt with Abercromby, was sharply engaged in the landing at Aboukir, and proved very efficient as light infantry. What actually happened to the Rangers after the VoL. LVIII. 
Peace of Amiens is obscure. There is good reason to believe they were disbanded, certainly a return of Foreign Corps in the Commons' Journals of 1807 does not include them until January Ist, 1805 , when they numbered 264 , but they certainly had been in vigorous being at times when the Estimates and similar sources of evidence afford no indications that they existed.

\section{THF FOREIGN REGIMENTS IN 1803.}

At the conclusion of peace in 1802 most of the foreign regiments were disbanded. 'Thus the York Hussars, into whose ranks had been drafted the relics of the other foreign cavalry corps, which the West Indies had reduced to skeletons, were given the choice of enlistment in British regiments or a free passage to Germany. Most of its foreign officers entered the Emperor's service. However, the speedy renewal of hostilities not only saved the surviving foreign regiments from the disbanding to which de Watteville's, Dillon's, and the Chasseurs Britanniques had already been sentenced, but led to considerable augmentations and additions. The French occupation of Hanover and the dissolution of the Hanoverian Army by the Convention of Suhlingen was followed by the escape to England of many Hanoverian officers and men, and their formation into a King's German Regiment, soon to be expanded into that King's German Legion, whose record is the brightest page in the story of the connection between Great Britain and Hanover. One may regard the Hanoverians as corresponding in the Napoleonic part of the war to the emigrés of ten years earlier: they fought under the British flag because they had wrongs to avenge and were fighting their own quarrel.

\section{NEW SOURCES OPENED.}

As before, prisoners of war and deserters were the main sources from which the foreign regiments in our service were recruited, but as the war spread to new theatres new sources of recruits were opened. Thus the British occupation of Sicily in 1806 was followed by the formation of a Sicilian Regiment in February, I807, which served in Egypt in that same year. Later on a Calabrian Free Corps was formed out of refugees from French oppression, and this corps, though mainly employed in Sicily, saw service on the East coast of Spain and helped in the reduction of the Ionian Islands. The capture of these islands opened the way to the enlistment of Greeks, a little corps of Ionian Greel Infantry being in the British service by 1812, while a battalion of Greek Light Infantry, formed in 1811, did so well at Sta. Maura that the formation of a second battalion was authorized, and the regiment was honoured with the title of the Duke of York's Greek Light Infantry. With this experiment the name of Sir Richard Church, one of the heroes of the Greek War of Independence, will always be associated, and 
the success of the venture was largely due to him. A rather less happy result attended the raising of two Anglo-Italian battalions in 1812 , one being formed out of Italian prisoners of war at Portsmouth, the other raised in Sicily. This battalion on being sent to Catalonia in I8I3 deserted freely-it had no less than 137 deserters in the year-and proved so completely untrustworthy that General Campbell found it necessary to disarm it and send it back to Sicily; but in Bentinck's littleknown expedition to Genoa in 1814 three Anglo-Italian battalions were employed, and with better results. Further afield, the capture of Cape Colony in 1806 was followed by the appearance in the Army Lists of a Cape Regiment, formed from Waldeckers in the Dutch service; on the reduction of Demerara in 1803 , most of the garrison took service with their captors, some joining the 6oth, the bulk being formed into a regiment called the York Light Infantry, which actually assisted only a few months later in the capture of another Dutch Colony, Surinam. This regiment spent its career in the West Indies, doing good service against the French on several occasions. It is sometimes stated to have served in the Peninsula, but this is inaccurate.

A Bourbon Regiment, raised in 1812 , was formed after the capture of that island in the previous year, most of its officers being English though the men were foreign. With these may be classed the regiments raised at Malta, two of Maltese Provincials being enlisted in 1803 , and brought up to a strength of 900 before the end of the year. In 1805 the Royal Regiment of Malta was formed in addition, the number of the Provincials being cut down, but it did not figure with conspicuous success when defending Capri in 1808 , and its establishment was reduced from I,000 for 1809 to 400 for 1810 , and next year it has disappeared from the Lists. Associated with the Royal Regiment of Malta in the loss of Capri, from which unfortunate episode they emerged without any loss of reputation, were the Corsican Rangers. This may be regarded as a revival of the previous corps, for Sir Hudson Lowe, its old commander, was commissioned in October, 1803 , to raise a corps, which was already over 500 strong by the middle of 1805 , and did conspicuous service at Maida, as well as serving very creditably in the Ionian Islands.

The most remarkable unit of all was a short-lived collection of Turks, Greeks and Albanians, got together at Malta in 1806 by an individual of scarcely even doubtful character called Froberg; he seems to have entrapped recruits into joining by promising that they should be made officers. This strange corps reached a strength of nearly 700 by the end of 1806 , but in 1807 it suddenly broke out into open mutiny and seized Fort Ricasoli, which was only recaptured with great difficulty, the fort having to be stormed before the last mutineers would surrender. It is hardly surprising that after this the corps was 
promptly disbanded. An earlier proposal to employ Albanians had been dropped because its author, General Villettes, was convinced on reflection of the unsuitability of that nation for regular discipline.

\section{THE BLACK BRUNSWICKERS.}

One, or rather two, corps which figured in the Army Lists for some six years entered the British service after most romantic adventures. When in I809 Austria took up arms against Napoleon, great efforts were made to rouse North Germany. The story of the gallant but ill-fated Prussian Hussar, Schill, is fairly well known, but that of Frederick VVilliam of Brunswick and his "Black Legion" is even more remarkable. Given the Duchy of Oels in Silesia in compensation for the absorption of his hereditary dominions into Westphalia after Jena, the Duke raised a "free corps" in 1809 to assist Austria, and did good service at its head. On the conclusion of the armistice after WVagram he undertook a raid into WVestphalia in the desperate hope of rousing his father's old subjects against Jerome. Unsuccessful in this venture and beset by enemies on every side, the Duke and his men found salvation at the mouth of the IVeser in the shape of an English squadron, on which they embarked. On arriving in England, the "Black Legion" was taken into the British service, the cavalry as the Brunswick Hussars, the infantry as the Brunswick Oels Light Infantry. Both units saw service in Spain; a detachment of the Hussars served on the East coast and did quite well in Bentinck's action against Suchet at Villafranca in September, 1813. The Light Infantry went out to Portugal in the autumn of 1810 and served under Vellington till the end of the Peninsula campaigns.

\section{DESERTERS AND PRISONERS.}

But it was from the prison-hulks and from deserters that the foreign regiments were mainly filled, and when one bears this in mind one is astonished to see how well many of these corps behaved. Of course, a German or a Swiss who had been forced into a French regiment might fight well enough under the British flag, might even be inspired by patriotism and by hatred of French oppression, but this was not to be expected of the bulk of the recruits obtained in these ways. It was in order to escape the horrors of the prison-hulks, and to get a chance of rejoining their friends that Frenchmen were ready to join the Chasseurs Britanniques or Dillon's. The first moment desertion was practicable they were off, and Wellington's dispatches are full of protests against employing such men in the Peninsula. It was from French deserters from the 6oth that Napolcon first heard of Moore's daring move, and as a rule deserters who came over in the Peninsula were shipped off to the York Light Infantry in the West Indies, where they 
could do little harm. Naturally, this, as Wellington points out, was calculated to discourage desertion, but the amenities of the prison-hulks were a powerful incentive to enlistment, and whatever may have been the quality of the recruits obtained there was no failure in the supply. In 1812 no less than 5,000 men were enlisted in England for "foreign and provincial" corps, in addition to 6,000 recruited abroad. This was an exceptional year, for in the Anglo-Italian levy, two new regiments of Canadian Fencibles, the Bourbon Regiment, and the and Greek Light Infantry, were all added to the establishment: 1813, when 2,200 recruits were obtained at home, and 3, 100 abroad, is perhaps more normal. But if recruits were plentiful casualties were very numerous. Between June, I803, and the end of 1813 , these corps lost by death no fewer than 16,000 men, and by desertion I I,600, while another 10,000 were discharged, many of them being invalided. Without going at any length into the statistics of the establishments and effective strengths of these corps, it may be said that on January ist, I804, they mustered in round numbers 17,000 , 1 I per cent. of the whole Army. Within four years the foreigners had more than doubled, and as the Army had only risen from 150,000 to 200,000 the proportion was now 18 per cent. By January ISt, I8I I, the foreign regiments came to 40,000 , but their proportion had declined to. I 7 per cent. Increases of 5,000 net in I 811 , and 7,000 in 1812 , brought them to well over 50,000 by the beginning of 1813 , and in the September of that year they reached their maximum, 53,729, over $20 \frac{1}{2}$ per cent. of the whole Army. After this the numbers declined; by the end of 1818 only some 25,000 remained, and these were destined to speedy reduction. It may be added that the proportion of desertions from the foreign regiments was always well above their percentage of the total strength of the Army. These statistics of course do not include the Royal Artillery, who out of an average total of 25,000 included some 2,000 K.G.L. Artillery and a small body of Foreign Artillery, usually between 400 and 500 strong, and apparently survivors of the companies raised before the Peace of Amiens. They do not seem to have seen any recorded active service.

\section{PROVINCIAL AND MISCELLANEOUS CORPS.}

But not all the regiments of whom account is taken in these returns of recruits raised, casualties and effective strength, really deserved to be called foreign. Along with genuine foreign regiments like de Roll's and the Sicilian Volunteers were regiments which should rather be reckoned as "Colonial" or "Provincial." One can distinguish in the first place the eight WVest Indian Regiments, the Cape and Bourbon Regiments already mentioned, three Ceylon corps, and the regiments of Canadian Fencibles, of which there were some six or seven, one, the New Brunswick Fencibles, being brought 
into the Line as the 104 th in 1809 , and replaced two years later by a new corps of the same name. These, though extra to the normal establishment, stand on a very different footing from such units as the Anglo-Italian Levies or the enlisted prisoners of war. who made up the York Light Infantry. Further, it is important to distinguish from the genuine foreign corps certain units sometimes erroneously classed with them, but which are called in the returns "British unnumbered regiments," or, in the more expressive phraseology of the Army Lists, "miscellaneous" regiments. These were really disciplinary battalions, quartered in the West Indies or on the West Coast of Africa, and recruited from men who accepted service in those unhealthy quarters as an alternative to the gallows or the halberds. One writer calls them the "condemned" regiments. It is perhaps worth while to try to disentangle these curious units. The original one was a corps which figures in the Army Lists from 1801 to 1803 as Fraser's or the Goree Corps; it was stationed on the West Coast of Africa, and distinguished itself in I $80+$ by recapturing Goree from the French. From 1804 to October, I807, this corps appears under the title of Royal African Corps, but in December, 1807 , its name was changed to Royal York Rangers. This is confusing, because a corps of York Rangers had been in existence from $1 \mathrm{So} 3$ till March, 1805, when it was reduced, apparently a foreign corps. During this time there had been a strong detachment of the corps at Guernsey, and in September, 1808, this, after being augmented to ten companies, was sent out to the West Indies. On this the companies in Africa became a separate corps, resuming their old title of Royal Africans, and being voted an augmentation of 200 rank and file in August, 1808, and further increased to over 900 for 1809 . The companies which went out to the West Indies as Royal York Rangers, served in the reduction of Martinique in 1809 , and of Guadaloupe in 1810 , and distinguished themselves greatly, having nearly 200 casualties, and earning warm praise from General Beckwith, and despite its disciplinary character, it seems to have been a thoroughly efficient battalion. What to some extent complicates the story is, that a corps of Royal West Indian Rangers came into existence in the course of 1806 , and included among its officers several who had been in the Royal Africans in 1806 . Yet another corps of the same character was added in 1813, the York Chasseurs, of which there is this only to be said, that the bulk of their men seem to have been Irishmen, and that they had a very distinguished officer as their colonel, Sir Denis Pack. They survived till 1818, when they were disbanded, as were also the Royalt York Rangers and the Royal West Indian Rangers, the Royal Africans continuing in existence till 1823. Now these corps, though sometimes described as "foreign," were in the main English, their officers certainly were, and so were the bulk of the rank and file, though both 
the Royal York Rangers and the West Indian Rangers included a large proportion of foreigners. In December, I815, there were five officers and 288 men of foreign nationality in the York Rangers, one officer and 178 men in the West Indian Rangers, one officer and two men in the York Chasseurs, one officer and one man in the Royal Africans. Somewhat similar in character was the corps raised in 1789 for service in New South Wales, and brought into the Line as the rond in 1809; it was partly recruited by men who were suffered to commute sentences passed by courts-martial by joining it, and in 1815 , when it had become the Iooth Foot, through the $95^{\text {th }}$ being taken out of the Line to become the Rifle Brigade, it had 154 foreigners in its ranks.

Strictly speaking, then, the returns of foreign and provincial corps somewhat exaggerate the extent to which we relied on the subjects of other powers. The regiments that were really purcly foreign were the six survivors of the days before the Peace of Amiens, with the Corsican Rangers, the Brunswickers, all the Greeks and Italians, the York Light Infantry, and Froberg's, and if one includes the 6oth, as one should, the total is approximately 3o. The King's German Legion, as the subjects of George III. in his capacity as Elector of Hanover, stand on a rather different footing.

\section{SERVICES OF THE CHIEF FOREIGN CORPS.}

When war broke out again in 1803 , four of the six old foreign regiments were in garrison in the Mediterranean, and it was in that region that they for the most part remained during the war. The Queen's Germans were in Ireland, de Meuron's still in the East Indies. Between them they mustered 3,000 out of an establishment of 4,900 , but they were rapidly augmented, and in 1813 de Roll's, de Watteville's and the Chasseurs had establishments of 1,605 each, Dillon's of 1,469, de Meuron's of 1,339 . By that time the Queen's Germans were no longer included in the list of foreign corps. They had been placed in the Line as the 97th Foot in 1804, and under this title had gone out to Portugal in 1808 , fought very well and suffered sharply at Vimiero, and, though left behind when Moore advanced into Spain, earned further credit at the Douro and Talavera, and in Beresford's siege of Badajoz. In the autumn of $181 \mathrm{I}$ it was so much reduced in numbers that it had to be sent home to recruit. The General Order in which Wellington takes leave of it and acknowledges its services is unusually complimentary in tone. Shortly before this it had been placed on the ordinary establishment, its depleted ranks betng replenished by British recruits. Naturally, until all its veterans died or were discharged, it continued to contain a large proportion of foreigners, I2 officers and 213 men out of an establishment of 720 in April, 1812, six officers and 9I men on December $25^{\text {th, }} 1815$, but after 181 it is no longer to be reckoned as foreign. Renumbered 
as the g6th in 1816 , when the Rifle Brigade were taken out of the Line, the regiment was disbanded in 1818 , but when the present and Manchesters, then the 96th, were raised in 1823 , they claimed to be a revival rather than a new corps, and the subsequent grant to them of the Egyptian and Peninsula honours of the Queen's Germans, even if open to cavillings from sticklers for legitimism, does at least preserve some memory of a gallant corps which deserves to escape oblivion.

\section{DE MEURON'S AND DE WATTEVILLE'S.}

De Meuron's seems to have remained in the East Indies till sometime in 1806 , when it was brought back to Europe and was in garrison at Malta. A drop in its effectives from $\mathbf{5 0 0}$ on January Ist, 1806, to 120 twelve months later is to be explained by the discharge of invalided and time-expired men, and the regiment's numerical weakness probably prevented it seeing active service again till in 1814 it was sent across the Atlantic to assist in the defence of Canada, thereby illustrating the far-reaching character of our Imperial responsibilities even in those days. Still 660 strong in December, 1815 , it was disbanded in the following year. De Watteville's also saw service in America. Before that it had gone from Malta to Sicily in I806, had played a creditable part at Maida and in various other episodes of our occupation of Sicily. In I8I I it was selected to join IVellington, but never got nearer him than Cadiz, though for a time it held Cartagena. It was unfortunate that so good a regiment should not have had the chance of distinguishing itself under Wellington, for it was certainly, even in ISII, a more favourable representative of the foreign regiments than those which actually served with him. Its record as regards deserters was quite good, as was de Meuron's also, and if in America it came rather to grief in the attack on Fort Erie in August, I8I4, the details of the affair are much too obscure to justify any severe criticism of the regiment, which otherwise did very well in Canada. If it did to any extent fall short of its Egyptian and Maida standards this must be put down to the very indifferent character of the material out of which it had to fill its ranks. By 1813 Napoleon had been so successful in checking emigration from Berne that the number of trueborn Swiss in the ranks had fallen below 300 , the remainder being men of all other nationalities from the prison-ships: Poles, Illyrians, Croats and others. To the end the officers were Swiss to a man, except for an English paymaster. Disbanded in 1816 de Watteville's Regiment assuredly had deserved well of its adopted country.

\section{DE ROLL'S AND DILLON'S.}

De Roll's seems to have managed to some degree to preserve its Swiss character. One reads of a draft of 500 Swiss 
being sent out to it in May, I8og, very likely they included some of the 4th Swiss of Junot's corps, who had come over almost wholesale to the British in Portugal in 1808 , and it certainly contributes much less than the average of the foreign corps to the number of deserters. It served in the disastrous Egyptian venture of $180 \%$, acquitting itself most steadily and creditably, shared in the reduction of the Ionian Islands, and then went to Alicante in 1812 and served for the next two years in the never very successful operations on the East coast of the Peninsula. It would seem that only part of the regiment went to Spain, for it had a detachment at Malta in 1813 , and in Murray's action against Suchet at Castilla in April, I8I3, de Roll's was apparently united with Dillon's, much in the way that the weaker battalions of WVellington's Army were combined as Provisional Battalions. As the regiment had still nearly $\mathrm{I}, 000$ rank and file in December, $\mathrm{I}^{8} \mathrm{I}_{5}$, it is hardly likely the whole corps was with Murray if this amalgamation was necessary. De Roll's survived till i816, out-lasting Dillon's by nearly two years. This regiment, though 400 strong in July, 1803 , seems to have been reduced later in the year, for in the return of January Ist, I804, it is omitted, as also from the Estimates for I 805 . However, if reduced, it was restored, and by January Ist, 1806, was again 400 strong, later on being brought up to over 700. It saw less service than the others, possibly because it was far more addicted to desertion, losing 42 in this way in 1811 , IOI in 1812 , and 126 in 1813 . Its only active service was on the East coast of Spain from I8I2 to ISI4. In December, 1814, it was disbanded.

\section{THE CHASSEURS BRITANNIQUES UNDER WELLINGTON.}

The Chasseurs Britanniques, like the Queen's Germans, had the good fortune to serve under Wellington in the Peninsula, and there is, therefore, no lack of information about it. Before going to Cadiz in 1810 it had served in Sicily, had suffered severely in Egypt in 1807 , and taken part in Stuart's abortive expedition to the Bay of Naples in I809. In January, 18II, the Chasseurs moved up from Cadiz to Portugal and were allotted to that Seventh Division whose cosmopolitan character earned it the nickname of the "MIongrels." Of its original six battalions only two were British, the others being the two Light Battalions of the German Legion, the Brunswick Oels Light Infantry, and the Chasseurs. The nickname of the division might well have been applied to the regiment, for a glance through the records of the Peninsula courts-martial, in which the Chasseurs appear only too frequently, will show that there was hardly a European country which was not represented in its ranks. Frenchmen are the most numerous, with Italians next, but there are not a few Slavonic names. Seeing the character of the material with which its officers-mainly emigrés 
or the sons of emigres-lhad to deal, it says volumes for them that they should have produced a corps as efficient and well-disciplined as the Chasseurs showed themselves on many occasions. At Vittoria, in the Pyrenees, and in the invasion of France they were constantly engaged and acquitted themselves creditably, but their great day was their first general action, Fuentes d'Onoro. When the Seventh Division had to fall back from its advanced post to Wrellington's main position, the Chasseurs had French cavalry swarming all round them, but, though repeatedly charged, they lept steady and beat off every attack, earning high praise from Vellington himself. The weak point of the regiment was its propensity to desertion, the incredible number of 150 men being said to have gone off in one night in August, I8I3, while the authentic figures for I8I I, I8I2 and 1813 are 139,17 I and 224 respectively. Little wonder then that Wellington made a rule of not entrusting the Chasseurs with outpost duty.

\section{THE BRUNSWICKERS.}

In the Brunswick Oels Light Infantry Wellington did not meet a much more favourable specimen of the foreign units. Sent out to Portugal in the autumn of 18 ro they were honoured by being posted to the Light Division, a privilege they did not long enjoy, as their tendency to desertion made them unsuitable for outpost work. Removed to the Fourth Division in January, I 81 , and then to the Seventh on its formation in March, they were present at Fuentes d'Onoro, at Salamanca (where they were in reserve), at Vittoria, in the Pyrenees and in the invasion of France. The Brunswickers were hardly one of the more efficient units in IVellington's Army; on the retreat from Burgos their misconduct upset Wellington's projected stand on the Douro by letting the French secure the bridge at Tordesillas; they figure prominently in the courts-martial records, and were a good second to the Chasseurs in desertion: thus in August, $181_{3}$, Wellington reports that go men had gone off from the regiment in the last few days, these being men enlisted from the prison-ships; clearly by 1813 men of the stamp of the original Black Brunswickers were difficult to obtain. Germany was already in insurrection, and there was no need to cross the seas to strike a blow for the liberation of one's country.

\section{THE SIXTIETH.}

The 6oth, though included among the numbered regiments of the Line, were to all intents and purposes a foreign corps, at any rate as regards the rank and file. The renewal of hostilities found all six battalions in the West Indies, and four of them remained there until the end of the war, with brief 
intervals, in which each was in turn drafted to the other battalions, the headquarters being sent home to recruit. They were usually sent to the Channel Islands, to which the Acts of Parliament limiting the services of foreign troops did not apply, and there filled up with prisoners of war and deserters. It is hardly wonderful that when the and and $4^{\text {th }}$ Battalions, after suffering this fate, were employed in Guadaloupe they should have misbehaved, or that the $4^{\text {th }}$ Battalion, which during a brief sojourn at the Cape received a draft of Austrian and Hungarian prisoners sold to the Dutch for colonial duty and taken over by us when the colony surrendered, should have been reported to be disaffected. In 1812 a 7 th Battalion was added to the regiment, which was further increased by the transfer to it as an 8th Battalion of a remarkable unit, till then known as the Battalion of Foreign Recruits. This had been developed out of a depôt formed at Cadiz for the reception of deserters and enlisted prisoners. Sometimes known as the Foreign Deserters the battalion justified its title, for although Cadiz being all but an island was not an easy place to escape from, they contrived to lose over 120 in this way in three years, and it is not surprising that it was never utilized for field service and was disbanded at the first opportunity.

The only battalion of the 6oth to see much fighting in the Peninsula was the 5 th, of whose origin I have already spoken. It had its full share and to spare, for the battalion was distributed by companies among the different brigades, so as to provide the additional light troops whom it was WVellington's system to oppose to the French tirailleurs, and thus it had the distinction of being represented both at Albuera and at Fuentes d'Onoro. Napier speaks of it as "composed of Frenchmen from the prison-ships," but this seems inaccurate, as, though a detachment of prisoners taken in Portugal in 1808 who were drafted into it proved most unsatisfactory, it was on the whole a well-conducted corps, and in the field did admirable service. Moreover, it would seem to have contained a considerable proportion of British officers, and even of British rank and file, which increased as the war went on. In 1808 two-thirds of its officers were foreign, in 1814 less than a half, while when at the end of the war the battalion was reduced and all its Germans were discharged it had still 400 British rank and file to transfer to the 2nd Battalion, one of the two which escaped disbanding in 1815. Not till 1824 ,id the 6oth finally get rid of the alien element, when it dropped the title of Royal Americans and adopted that of the Duke of York's Rifle Corps.

\section{FOREIGNERS IN BRITISH REGIMENTS.}

It should also be mentioned that there were scattered throughout the ordinary regiments of the Army a fair number of foreign officers and men, just as one finds some of the foreign regiments containing not a few English officers, notably 
Dillon's and the York Light Infantry. A return of 1812 gives 42 officers and 577 men of foreign nationality as belonging to regiments serving at home, but adds that many of these were persons of colour employed as bandsmen, while nearly a third of the total belonged to the 97th. Another return of March, 1815 , gives 66 officers and 1,650 men of foreign birth as serving in British regiments other than the 6oth. Of these the Royal York Rangers had five officers and 270 men, the Royal WVest Indian Rangers two officers and 293 men, the 8oth Foot 55 men, and the Iornd (the old New South TVales Corps) 173. The 97 th made no return but figure in a similar list for December, I815, with just under 100 of all ranks. The total in this list is 100 officers and 1,908 men, of whom the Royal Scots had nearly 100 and the 2oth Light Dragoons nearly 5o. Sergeant Landsheit, almost the only foreigner in our service who has left an auiobiography behind him, passed into the 20 th when the York Hussars were disbanded, and from them transferred to the Foreign Hussars as sergeant-major. This was a small corps of mounted infantry formed from the foreign regiments in Sicily in 1810 and attached to the 2oth as an additional troop; it accompanied the zoth to Catalonia, being then about 7o strong. The presence of so many foreigners among the Royal Scots may possibly be connected with the employment of the $4^{\text {th }}$ Battalion at Stralsund in 1813 and 1814 , but why the 8oth should have contained as many as $50 \mathrm{I}$ am unable to say.

\section{THE KING'S GERMAN LEGION.}

I have already trespassed on your patience to a most unwarrantable extent, and yet I have barely touched upon the best and most interesting of all these "foreign" corps. But the King's German Legion may claim that as the naturalborn subjects of George III.-even if it was as Elector and not as King that they owed him allegiance-they should not be included in this category. Moreover, they are additionally differentiated from these other corps of whom I have endeavoured to tell you something, in that they have left their memorial. Their history has been most adequately written : in 1837 by an Englishman, Najor Ludlow Beamish; more recently and more fully by a Hanoverian officer, Herr Schwertfeger, whose book may well be called a model regimental history. And no one can visit Waterloo without being reminded of the gallant deeds of the Legionaries. On the east of the great high road is the monument erected in their memory. Hard by just across the road is an even better memorial of one of the brightest incidents in the "crowning mercy" of the great struggle against Napoleon. The gallant defence of La Haye Sainte by Baring and the 2nd Light Battalion of the Legion will surely not be forgotten while the shot-scarred walls of the little farmhouse stand as a silent testimony. 


\section{DISCUSSION.}

The Chairman: I think you will agree that we have spent a most profitable hour in enlarging our linowledge of a subject into which the lecturer has been delving where practically no man has dug before. As he said himself, of all these foreign corps the German Legion only has been adequately written upon, and to the best of my knowledge there is hardly one of the other regiments into the history of which anybody has ever talien the trouble to enquire. The only other two that have been dealt with in any way are the $97^{\text {th }}$, the old Queen's Germans, and the 5/6oth, which have had their annalists, because both became in the end British Line battalions. WVe are going some day to have from Major Lewis Butler the whole history of the 6oth in the West Indies, but that is not before us to-day.

With the exception of the $97^{\text {th }}$ and the $5 / 60 t h$, we may say that we have had no recorded history of the foreign corps. For the most part it was very difficult to find out even when they were raised, and when they were disbanded, until Captain Atlinson put together this most lucid and valuable paper. Of course, it is a little difficult to draw general deductions and conclusions from such a mass of detail, but I daresay it will have occurred to you to think, as it occurred to your Chairman of to-day, how extraordinarily lucky, on the whole, we were with our foreign troops. Repeatedly other Powers have been betrayed in the critical moment, not by individuals who have deserted, but by entire corps which went over to the enemy. In the whole of the history of the 50 or 60 corps with which Captain Atkinson dealt there are only two occasions when anything of that kind happened-one was at the expedition to Quiberon, which, after all, was an ćmigrés' expedition, not an English expedition; it was wrecked because a good many of the French rank and file from the prison ships refused to fire on the Republican troops. The second occasion, which Captain Atkinson alluded to but did not narrate, was when the Second Italian Levy, on the coast of Spain in 1813, plotted to betray the villages outside Alicante to the French, and with them the Spanish troops under General Whittingham that were assisting in garrisoning them. That plot very nearly came off. Fortunately informers told Vhittingham, and it was possible to disarm the Second Italian Levy, to shoot some ringleaders, and to ship the rest back to Sicily before anything disastrous had happened. But those two examples constitute a singularly small list, if one considers what perpetually happened, for example, to Napoleon with his foreign troops.

There are one or two other suggestions that offer themselves for consideration. The first is, how far was this use of foreign troops more or less a necessity during the earlier years of the war owing to the great stress caused by necessity for recruiting the Navy. We may say, roughly, that from 1795 down to Trafalgar, England was in serious danger of naval invasion by France, and that therefore the Navy had to be kept up to an altogether exceptional strength, which after 1805 was no longer so much necessary. When you have got a limited population to draw upon, and a great strain on that population already being made, perhaps it was not so very bad from the point of view of national economy to put into outlying or insalubrious garrisons troops that were not the best that could be procured. To have wasted the men of the Peninsular Light Division in occupying New South Wales or San Domingo or Tobago would clearly have been absurd. May we perhaps say it was really 
economical to have a foreign garrison made up of such battalions as the $1,2,3,4,6 / 5$ oth in the West Indies? They were composed of material that did not tell on the recruiting powers of Great Britain at a time when every available British recruit was wanted for the first line duty in the Peninsula and the Mediterranean.

There are a few questions I should like to ask Captain Atkinson, which he, out of his unrivalled lnowledge of these people, may be able to answer. There were, as he says, many foreign general officers at this time in the British Army. I have always in a vague way supposed them to be Hanoverians, but I am informed that a good many of them were not. Would he tell us what really was the nationality of persons like Sontag, who commanded a division in the Peninsula, and of de Bernewitz, or Jonquières, who commanded a brigade in the same war; and of those regiment-raising gentlemen of whom he told us so much, Hompesch and Lowenstein? Captain Atkinson tells us that he thinks the $97^{\text {th }}$, the Queen's Germans, had a Swiss origin. That is technically correct, but I should be inclined to call them German from the first, for the reason that although they were raised from Spanish regiments called Swiss, the men we took prisoners in Minorca were not really of Swiss nationality. In the old Spanish Army if you spolse any sort of German you were called a Swiss, and put into a Swiss corps; if you spoke any sort of Romany language you would be called an Italian, and put into an Italian corps. I imagine that these recruits, brought from Austria and put into the Swiss regiments which were taken prisoners at Minorca, were Austrians of sorts rather than Swiss, although, no doubt, they were in Swiss regiments when captured. "Swiss" was a Spanish technical term which covercd anything, just as in the latter pait of the war in the British Army "Brunswicker" was a very vague term which might cover a Croat, a Pole, or a Dutchman.

It is a little interesting to notice the point that the Corsican Rangers, whom Captain Atkinson mentioned as having distinguished themselves at the defence of Capri, were always commanded by Sir Hudson Lowe, who showed such enormous power of dealing with very tiresome and refractory Corsicans, that for this cause he was chosen to be the Governor of St. Helena. He was the one person of high rank in the British service who had a great experience of Corsicans, and that is the reason he was selected to be Napoleon's gaoler.

The mutiny of the strange Greek regiment that was in Malta in 1806, Froberg's regiment, had an even more theatrical ending than Captain Atkinson mentioned. The last few scores of uncaptured men blew themselves up in the great magazine of Fort Ricasoli, after the large majority, who were not prepared to go to extremes, had surrendered.

I have only one more note. This is an expression of wonder at the great difference which, as Captain Atlinson hinted, existed between the loyalty of the $5 / 60$ th and that of all the other foreign regiments in the Peninsula, with the exception of the King's German Legion. IVhen IVellington wished to strengthen the light troops of all the brigades of his army-when he wished to add good skirmishers to cvery brigade, it was this once wholly foreign, and still largely foreign, battalion that he chose to split up, and to distribute by companies among all the brigades. They had particularly good opportunities for desertion, and though still for the most part foreigners they did not take advantage of them. It was a very great distinction for the $5 / 60 t h$ that they had unique opportunities 
for absconding to the French Army, from which so many of them came, and that they did not do so. They were a most reliable body of light troops throughout the war, and very rightly earned the little book of record, "Celer et Audax," which General Rigaud dedicated to their memory.

Colonel Sir Lonsdale Hale: I should like to ask Captain Atlsinson if he can solve a conundrum which has lately occurred to me. There is no doubt in my mind that in order to obtain the extraordinary amount of information which he has put into his lecture he must have collected a huge mass of other information from which to sift it out. I do not know why he starts at 1797 , and not before, and I will give him the reason I say so. I happen to be going through 14 volumes of military manuscript which deal with the Presidency of Madras, from 1774 up to 179.4. I have got through only about 1,600 of these Orders, but I find that in 1782 , the $5^{\text {th }}$ and 16 th Hanoverian Regiments are mentioned. Then there comes in later a I4th Hanoverian Regiment, and only yesterday I came across this Order, dated July 17 th, 1787 : "Col. Wangenheim will receive certain allowances the day after his arrival at Madras, being the day he assumes the command of the Electoral Troops." They are named there as "Electoral Troops," belonging, I presume, to the Elector of Hanover; and it would be very interesting if the author would look into that big heap from which he has been bringing us these valuable siftings and tell us how it was that Electoral Troops were ever employed in the East Indies. I have got through only as far as $17 \delta_{9}$; there are six or seven volumes yet to be done, and it will be of great interest if Captain Atkinson will take the trouble to look at the heap and see whether there is anything about these regiments in it.

Lieut.=Colonel W. H. James: I should like to point out a thing that may be of interest to many of us, namely, that the one great bond which lsept together all these miscellaneous regiments under the British flag was the fact that they were all drilled in English. Whether it was the King's German Legion or the Sicilians, or any of the other corps, every one of them was drilled in English. There are in existence translations of our field exercises and our cavalry drill into German for the benefit of the King's German Legion. There is a book in Italian which deals with the English drill which was published in Sicily for the benefit of the troops raised in Sicily about 1806 onwards. There were many miscellaneous regiments. The Albanians, for instance, were the same. All ${ }_{2}$ and every one of them were drilled in English. The Portuguese Army raised by Marshal Beresford was drilled in English, and $I$ believe $I$ am right in saying that for many years afterwards English was maintained both for the manual and the platoon exercises. It is very interesting to find that the system we found so useful for drilling native troops in India was equally applicable for drilling foreigners. The Chairman will agree with me that the great reason why we had not any troops available for fighting in Europe was that our so-called statesmen of the epoch did not understand strategy. They wasted their troops all over the world; there were huge garrisons in the West Indies where nobody could get at them. They seem to have had a preference. for the most pestilential spots they could think of, and they generally wasted our resources. Had we taken proper advantage of the troops we possessed I believe we might have brought Napoleon's career to an end in 1796. Most emphatically in 1807, after the terrible battle of Eylau, we might, if we had kept faith with the 
Czar, which we did not, have put such a force in Poland, or possibly Hanover, when they had only to deal with the Army Reserve, as would certainly, I believe, have brought Napoleon's career to a termination then. Had we done so Austria would have found heart of grace and have attaclied Napoleon in 1807 instead of waiting till 1809 . That I believe to be the real solution-the idiocy of our statesmen.

Dr. Miller Maguire: It appears to me that a kind of pall of sadness and depression has been hanging over the meeting, not because there was any lack of interest in the extraordinarily learned paper of the lecturer, but bccause we all felt sad as we listened to the record he gave us of the inefficiency, incapacity, degradation, and all the marvellous methods whereby the British flag was kept flying, when, as the officer who has just sat down has said, but for this incapacity and inefficiency the war might have been over long before.

According to Napier, whose brilliant work is now left out of the study of British officers, if there was anything that could diminish the interest we all should feel as Englishmen, Scotchmen, Irishmen-Britons and Colonists - in the records of our regiments, it is the fact that not a single real Englishman is taught anything at the public schools beyond a minimum of our own military history, without which no foreign officer could become a sergeant, let alone a cadet. I know that I am spealsing the truth; if I am not I hope the gallant officer will correct me; but I know that you, Sir, have said something very similar. This will never do. The courses must be changed at once, and as much attention paid to our records and literature: poetry, oratory and history as foreigners of any civilized State pay to their literature and annals. We have here a new era of operations for our minds, to show us that in the records of these regiments we have matters that should interest every county, parish, and person in England, of all ranks. The gentleman who has just sat down has told us that we are justified in criticizing the incapacity which leads to such a state of despicable indifference to British records of glory. But is there not an extraordinary similarity between what occurred in past crises of voluntary recruiting and cadging for soldiers: those times and what is occurring to-day? Are ne not searching for recruits for Regulars, and, indeed, Home Guards, Territorials, by every conceivable method? Is it not the case that we are looking out everywhere for recruits? Our Regular Army is in an even more benighted condition than it was a hundred years ago for want of men, and our militia has disappeared. Is there not something desperate in the state of this parody of Denmarls, these British Isles, that such things should be? If what was stated in every daily paper last week be true, we are in a worse state now than we were at the beginning of the Peninsular IVar; we are in a worse state now than we were after 'Trafalgar. At Trafalgar we had a Navy' stronger than every Navy in existence, and yet we were able to keep up some kind of an Army. An Army far stronger absolutely and relatively than to-day's. If this case be true, undoubtedly it is the duty of every lady and gentleman here to take every opportunity of using the text of the opener of the discussion to emphasize the necessity of being wise in time, because it is simply madness to do otherwise. In the five minutes that remain to me I should like to deal with some of the points that the gallant lecturer has raised. It was the most common thing in the world, from the religious wars beginning in 1618 on a grand scale, down to the Peace of IVestphalia, for people of any race that happened to be Protestants to 
serve a Protestant leader, and for any man who happened to be a Catholic to serve a Catholic leader. If I am not mistaken there were 12,000 Britons in one battle in Germany at the Lech, and Scotch crowded the armies of Gustavus Adolphus, and those Scotchmen were the nucleus of the armies at Dunbar and in the North of Ireland, under Leslie and under Monro. I would not have been here but for some Scotchmen in the service of Cromwell in the North of Ireland, and I would have been just as glad if he had kept his military strategists at home. Take the Duke of Marlborough. If I am not greatly mistaken he learned the art of war after a course of study of Vegetino in the camps of the Frenchman Turenne, and yet he became one of the most illustrious of our Generals. Some of our ablest opponents on the field were Roman Catholic exiles-illegitimate soldiers of fortune. Marshal Saxe, already referred to on this occasion, was a son of a Polish King, was in the French service, and led the Roman Catholics of the Irish Brigade against the Germans and British of George II. Berwick was the natural son of James II., and defeated our forces under Galway at Almanza. Mercenary troops are either no use or very valuable and costly. A speaker mentioned two dollars a head being paid for a man, body and soul, as a white slave, to go to India to keep up the British Empire. I wish we could get them at three times the price now. Why, Sir, a Cabinet Minister gets Ir $_{4}$ a day, as much as three colonels. I was offered about a sovereign coming down here if I could recruit any kind of a soldier at all. I happened to be already a Territorial-Heaven knows why-and I could not take the bounty. But an Irishman called $O^{\prime}$ Brien was offered a certain sum, which he took, to join the service of the father of Frederick the Great. Do you remember how much it was, Sir? What do you think the value of that Irishman was- $£ 1,300$. You sce how some fellows who joined under-estimated their value. But he was seven feet high and built in proportion. All through the lecture Captain Atlsinson has been interesting in the highest degree.

Colonel E. M. Lloyd : I cannot help endorsing a great deal of what Dr. Miller Maguire has said as regards the employment of foreign troops. You, Sir, gave an explanation of their use which is a very plausible one, namely, the extreme stress on this country in 1805 , when invasion was threatened; but that was not the time when we began to use foreign troops or left off using them. We employed Hessians against the Highlanders in 1745, and also to reduce our Colonies to submission; and only 60 years ago, in the time of the Crimean War, we voted 40,000 additional troops which we could not raise, and then we set to work to raise a German Legion. It was the question of buying in the cheapest market. The average German was cheaper than the average Englishman, and therefore Germans were bought. As regards the lecture in general, I feel we are very much indebted to Captain Atkinson, who has added this obligation to the obligations which we owe him already, for his admirable reconstitution of IVellington's Army with all its divisions at different periods. It is a most valuable piece of work. I wish he could have found time to touch, not only upon the numbers of German troops that helped us, but upon their influence on our own drill and handling during that war. I believe a very interesting lecture might be given on that subject. There was a remarkable paper by Captain Fuller in the last number of the JouRnal of this Institution about light troops, in which it was shown that the drill of Sir John Moore and the formation of the 
Light Brigade at Shorncliffe owed a great deal to Baron von Rottenburg's Manual of Light Infantry. The manual was published anonymously, but Captain Fuller showed it must have been written by him. He was an oflicer of the $5^{\text {th }}$ Battalion of the 6oth. There werc others like Villiam Stewart, who also contributed, and who had picked up their Isnowledge in Germany. Men like Graham and Craufurd had served with foreign armies, and had there learnt that part of military duty. Then, again, in the pages of Napier we have praise of the Hussars of the King's German Legion, and undoubtedly our cavalry learnt a very great deal about outpost duty from them. I fancy it might be shown that we were quite as much indebted to the Germans for what they taught us about minor warfare, of which they had had so much experience, as we were to their additional numbers for swelling our scanty forces.

Captain C. T. Atkinson, in reply, said: The officers, Professor Oman, were nearly all Germans. One man with the French-sounding name, de Jonquières, was a King's German Legion officer, probably a Huguenot who had emigrated to Germany. There were a lot of them in the Prussian Army. WVith regard to the Hanoverians in India in 1781 , three regiments were hired from George III. as Elector of Hanover, by George III. as King of England. One went to Gibraltar and served in the siege; I think they were the I2th. Those who went out to India were there certainly in 1786 when Lord Cornwallis came out as GovernorGeneral, because he pointed out that the Hanoverian troops were not at all suited to the climate, and there are several letters in his despatches requesting the Government to take these Hanoverians home. He says they are even worse than the Company's Europeans. General Wangenheim was their Colonel. He captured Marshal Bernadotte at Cuddalore, when Bernadotte was a sergeant of the French infantry and wounded there. They stayed, I think, in India till about 1789 or 1790 . They certainiy were not serving against Tippoo in $179^{2}$.

Colonel James said that the bond which kept the regiments together was the British drill; I think, personally, it was quite as much the British officers. A good many regiments composed of inferior material did quite well because of their British officers. I think it is the case that the Portuguese used the English words of command until a very late date. As to the influence of these foreign troops on our men, to which the last speaker referred, one must remember that the men of the Light Division always preferred to have the German Legion Hussars working with them, because those Hussars were not so excited in coming in with messages. The British Dragoons used to gallop into the outposts, and upset everybody, but the Germans rode in slowly. At one time the Light Division used to shoot at the British Dragoons if they came in too fast. By the end of the war there was one British regiment, the $14^{\text {th }}$ Light Dragoons, I think, which had learnt to do its work quite as well as the Germans. I do not think I have anything more to add except to apologize for the extreme length of my lecture.

(During the course of the Discussion, the Chair was vacated by Professor Oman, who had another engagement, and taken for the remainder of the meeting by Colonel Sir Lonsdale Hale.)

Colonel Sir Lonsdale Hale: Professor Oman was obliged to go away, and hence I am taking his place. The duty $I$ have to perform is a pleasurable one-offering our thanlis to Captain Atkinson for not only 
the lecture he has given us to-day, but the paper which he has written, which contains information that you cannot get elsewhere, and that paper will remain as a record of most valuable information. We do not look upon the lectures given in this theatre merely as lectures; we look upon them, as well, as papers. They go into the Joursal, and are there read by nearly 6,000 people all over the world. Therefore we do not care only for what is called a good lecture, but we want something solid and real and good, such as Captain Atkinson has favoured us with. I am very much impressed at the extent of what I may call the dustheap from which he collected this huge amount of valuable information, for on the spur of the moment he was able to answer the conundrum about the Hanoverian Regiments. I am accustomed to this sort of research, and that gives me a real idea of the enormous extent of reading and research that has been undertalien by Captain Atkinson in order to produce this paper. I am sure I may convey to him from you and from the Council our sincere thanlis for the admirable lecture he has given and the paper he has written, and I will, in the absence of Professor Oman, ask you to allow me to convey to Professor Oman our thanks for his presence here. We like to get here in the Chair on these occasions, when we get an expert such as Captain Atlinson bringing forward a particular subject, an older expert to talse the Chair, and we were fortunate enough on this occasion to get the services of so well known an expert in military history and its details as Professor Oman.

The Votes of Thanks were carried by acclamation, and the meeting terminated.

Lieut.-General Tyrrell sends the following remarks which he had intended to have made had he not, unfortunately, been prevented from attending the lecture :-

With regard to the presence of Swiss in the Royal American Regiment, M. May, in his "Military History of Switzerland," published circa 1780 A.D., states that during the Seven Years' WVar King George II. of Great Britain commissioned Colonel Jacques Prevost, of Geneva, to raise a regiment of foot of four battalions for the King's service; this was done, and Colonel Prevost took great pains in securing the services of the ablest and most experienced officers; but when the regiment was mustered and ready for service, the British Parliament refused to furnish the funds for its maintenance, and the King and the Colonel were left in an awlsward predicament. The matter was arranged by malking over two battalions to the Hon. East India Company, and the two remaining were made the $5^{\text {th }}$ and 6 th Battalions of the Royal American Regiment.

Colonel Prevost and his brother accompanied these battalions to America, and both rose to high rank in the British service. Another officer of these battalions, whose name, I think, was Bouquet, commanded in frontier wars against the Red Indians, and died Governor of Savannah. When I first read Orme's delightful " Narrative of the Military Transactions of the British Nation in Indostan," I was struck with the foreign names of the officers who were Clive's companions and subordinates. Gingens, Calliaud, Polier, etc. I afterwards found out that these were Swiss officers, belonging to two companies of Swiss soldiers which the East India Company had engaged to fight its battles, how and where I do not know, for M. May does not mention them in his history. The 
presence of these foreigners in the Company's scrvice perhaps accounts for the title of "European" given to its white regiments.

Histories of the Swiss Regiments of de IVatteville, de Roll, and de Meuron in the British service have been published in Switzerland; the former in German, the two latter in French. Von Wattenwyl, or de Watteville, was Major of the Bernese Regiment in the service of France, the senior Swiss Regiment in the French Army. On the outbreak of the Revolution, de VVatteville led the regiment back into Switzerland, where it was disbanded, and most of its officers and soldiers enlisted in the service of Austria. Four double-battalion regiments of Jägers were raised from the Swiss soldiers set free from the French service, and formed part of the Imperial Army, though they were paid and maintained by English money. After the Peace of Luneville, the remnants of them were disbanded, and out of them de IVatteville formed his regiment for the British service.

The "History of de Roll's Regiment" says that in the Peninsula the remains of Dillon's Regiment were drafted into it, and the regiment thereafter went by the name of Roll-Dillon's.

After the peace of $\mathrm{ISI}_{4}$ it was sent to garrison Corfu, and after the. peace of 1815 it was brought to Venice and disbanded there.

The "History of de Meuron's Neufchâtel Regiment" had coloured prints of the flags and uniforms of the regiment in the Dutch and in the British service. The book is now out of print and copies of it are rare. The regiment did not accept service under the British flag until the Stadtholder of Holland, who had taken refuge in England, wrote to release it from its allegiance to him; for the Swiss were never known to violate their military oath. Relics and trophies of de Meuron's Regiment may to-day be seen in the Museum at Neuchâtel, and its name may still be seen on military monuments at Bangalore and other stations in Southern India. It was the only Swiss mercenary corps that ever served in all the four continents: under the Dutch flag at the Cape of Good Hope, and under the British in India, in the Channel Islands and the Mediterranean, and finally in Canada, where many of its men settled, whose descendants aredoubtless to be found there to-day. 